\title{
Estimates of Water Use Associated with Continuous Oil and Gas Development in the Permian Basin, Texas and New Mexico, 2010-19, with Comparisons to the Williston Basin, North Dakota and Montana
}

\section{Water Use During Oil and Gas Extraction}

Oil and gas are extracted from continuous oil and gas (COG) reservoirs by directionally drilling and hydraulically fracturing the reservoir rock surrounding the borehole. Hydraulic fracturing techniques involve injecting water and sand, or synthetic materials called proppant, under pressure into the borehole to generate stress and open fractures in the reservoir rock (Valder and others, 2018). The fractures are held open by the proppant, enabling extraction of reservoir fluids, typically a mix of water and oil.
The extraction of oil and gas from COG reservoirs using hydraulic fracturing requires large volumes of water (Jiang and others, 2014). However, estimating the total volume of water used to extract oil and gas from COG reservoirs is difficult because geologic properties, drilling depth, and the requirements of hydraulic fracturing vary by well. Three types of water use associated with COG development are (1) direct water use (used for drilling, cementing, stimulating, and maintaining [hydraulic fracturing and borehole maintenance] the well during production); (2) indirect water use (used at or near the well for crew camps, well pad upkeep, and dust abatement on roads); and (3) ancillary water use (all other water used during the life cycle of COG development, such as domestic and public supply, including recreation) (fig. 1; Valder and others, 2018).

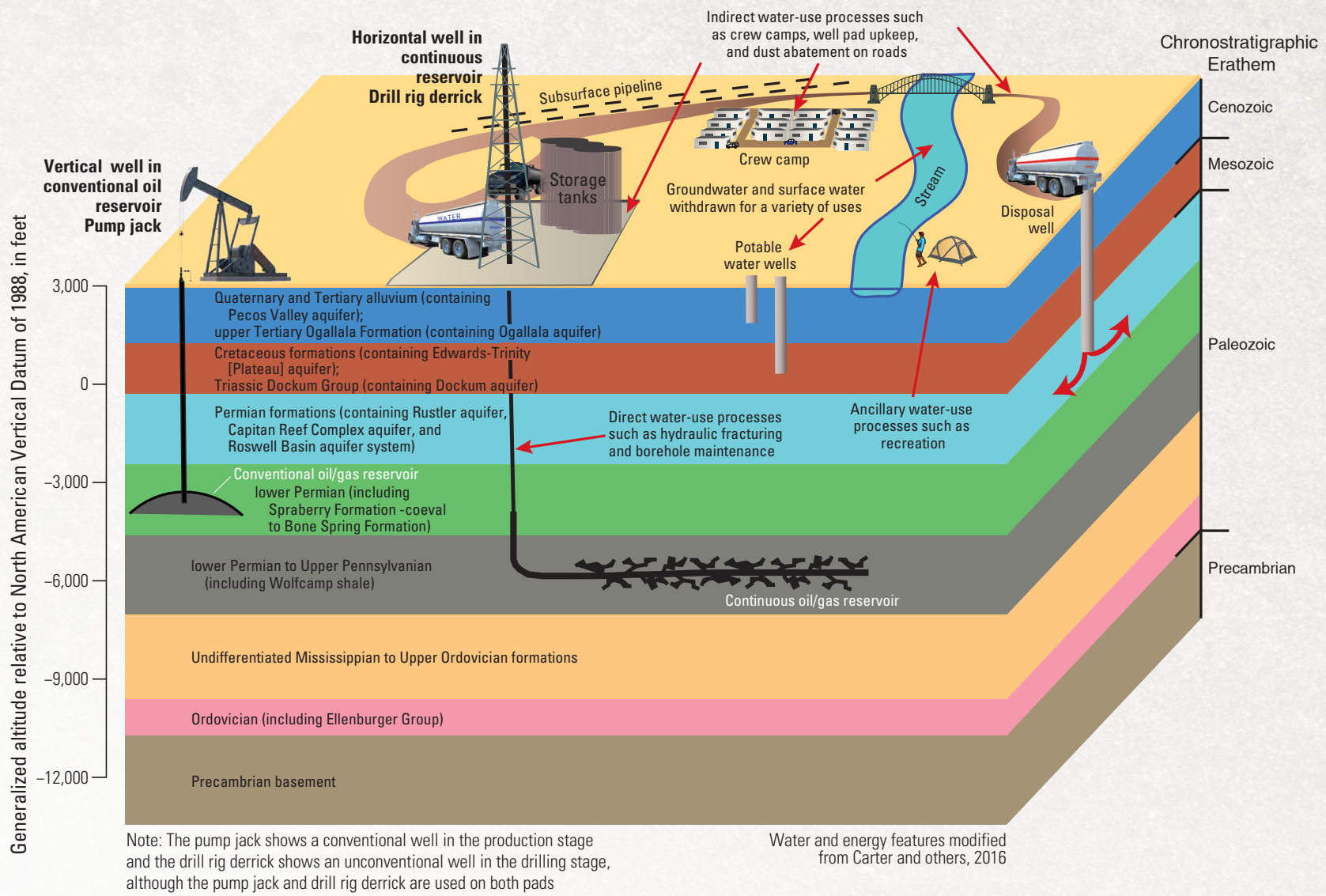

Figure 1. Schematic showing various water and energy features of conventional and continuous oil and gas development in the Midland Basin of the Permian Basin (modified from Carter and others, 2016). Oil and gas extraction, whether in a conventional or continuous reservoir, targets specific stratigraphic sequences in the Permian Basin. Direct water use is greater with continuous oil and gas wells owing to water needed for hydraulic fracturing. Indirect and ancillary water use also occurs during well drilling and development (modified from fig. 3 in Valder and others, 2021). 


\section{COG Extraction Methods}

The Permian Basin, in west Texas and southeastern New Mexico (fig. 2), is one of the largest conventional oil and gas reservoirs in the United States and is becoming one of the world's largest COG reservoirs (Scanlon and others, 2017). Advances in technology have enabled oil and gas to be extracted from reservoirs that historically were developed using conventional, or vertical, well drilling techniques (Valder and others, 2018). Conventional oil and gas reservoirs have discrete deposits that are well defined and are typically trapped by an overlying geologic formation or caprock, whereas COG reservoirs contain deposits that are distributed evenly throughout the geologic formation, typically have much lower permeability (the capacity of a porous rock to transmit a fluid) than the conventional deposits, and require specialized horizontal extraction techniques (McShane and others, 2020). The methods to extract the oil from the two different reservoirs require differing amounts of water, and the horizontal extraction methods typically require substantially more water. In 2015, the U.S. Geological Survey (USGS) started a topical study to quantify water used during COG development. The Permian Basin, which contains both types of reservoirs (continuous and conventional), was the second basin in the United States in the USGS's topical study to quantify water used during COG development.

\section{Developing Methods to Estimate Total Water Use}

The topical study to quantify water use in areas of COG development led to the development of a method to assess the life cycle of water use in areas of COG development (described in detail in Valder and others, 2018, 2019).

A conceptual model and an analytical framework for estimating water use related to COG development, including uncertainty (Valder and others, 2019), was initially used to estimate COG-related water use in the Williston Basin (phase 1) in North Dakota and Montana (fig. 2) (McShane and others, 2020). Then, the conceptual model and framework were used to analyze water use related to COG development in the Permian Basin (phase 2). Analysis of water use in the Permian Basin began in 2019.

Data needed to use the model and analytical framework in the Permian Basin were compiled from several sources and are available in a data release (Ball and others, 2020). These data include water volumes and well information (FracFocus, 2020; IHS Markit, 2020; Texas Water Development Board, 2020; U.S. Geological Survey, 2020), climate data (Parameter-Elevation Regressions on Independent Slopes Model [PRISM] Climate Group, 2020), and population data (U.S. Census Bureau, 2020).

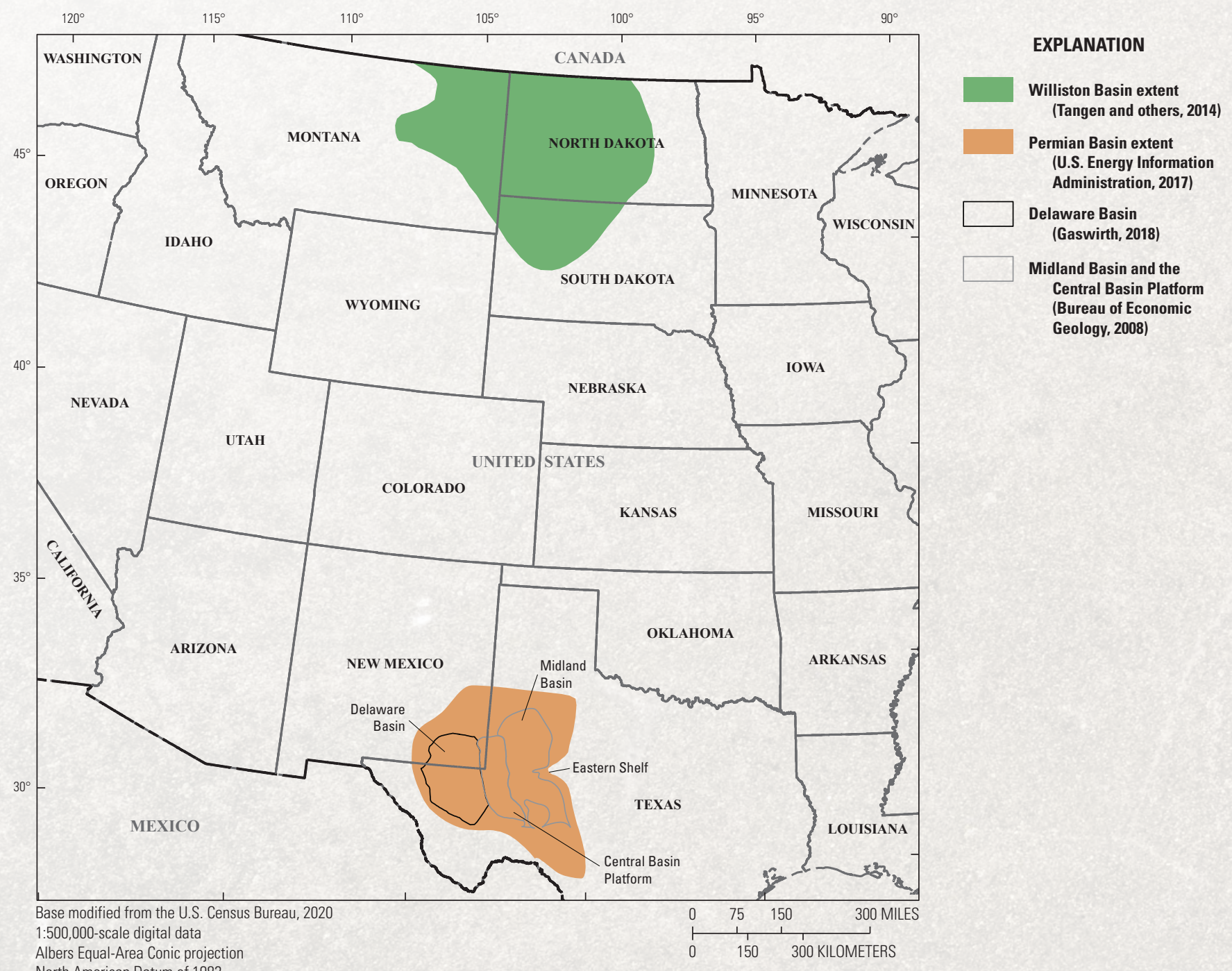

Figure 2. Location of the Permian Basin in Texas and New Mexico and the Williston Basin in North Dakota and Montana (modified from fig. 1 in Valder and others, 2021). 


\section{Estimating Water Use in the Permian Basin}

Estimates of direct water use indicate an upward trend in the amount of water used in the Permian Basin from 2010 to 2019, ranging from 3,003 million gallons per year (Mgal/yr) in 2010 to 72,220 Mgal/yr in 2019 in Texas and from $353 \mathrm{Mgal} / \mathrm{yr}$ in 2010 to 11,403 Mgal/yr in 2019 in New Mexico (fig. 3). In both States, direct water use increased steadily during the study period, nearly tripling between 2016 and 2018. Indirect and ancillary water use did not increase at the same rate as direct water use, and the ratio of direct water use to indirect and ancillary water use was larger in Texas than in New Mexico (fig. 3). The difference in direct water use between the two States is a result of differences in the number of oil and gas wells developed per year (approximately 4,000 wells were developed in Texas in 2019 and approximately 900 in New Mexico in 2019) and the volume of water used per well (Ball and others, 2020).

In the Permian Basin, estimates of water use per well for hydraulic fracturing were 29 times higher in 2019 than in 2010 (fig. 4). Direct water use for drilling and cementing were small compared to direct water use for hydraulic fracturing (fig. 4).

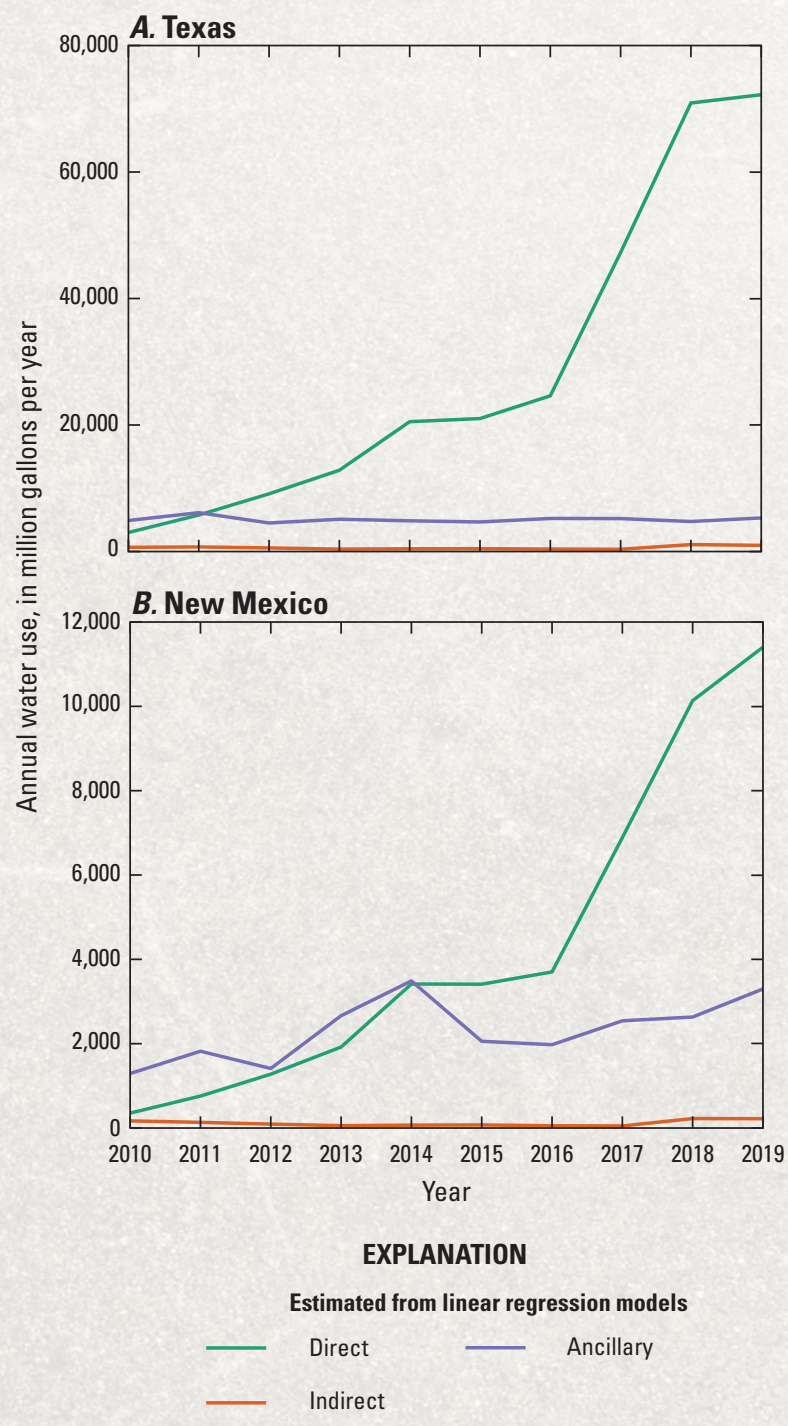

Figure 3. Direct, indirect, and ancillary water use in the Permian Basin from 2010 to 2019. $A$, Texas. $B$, New Mexico (modified from fig. 5 in Valder and others, 2021).

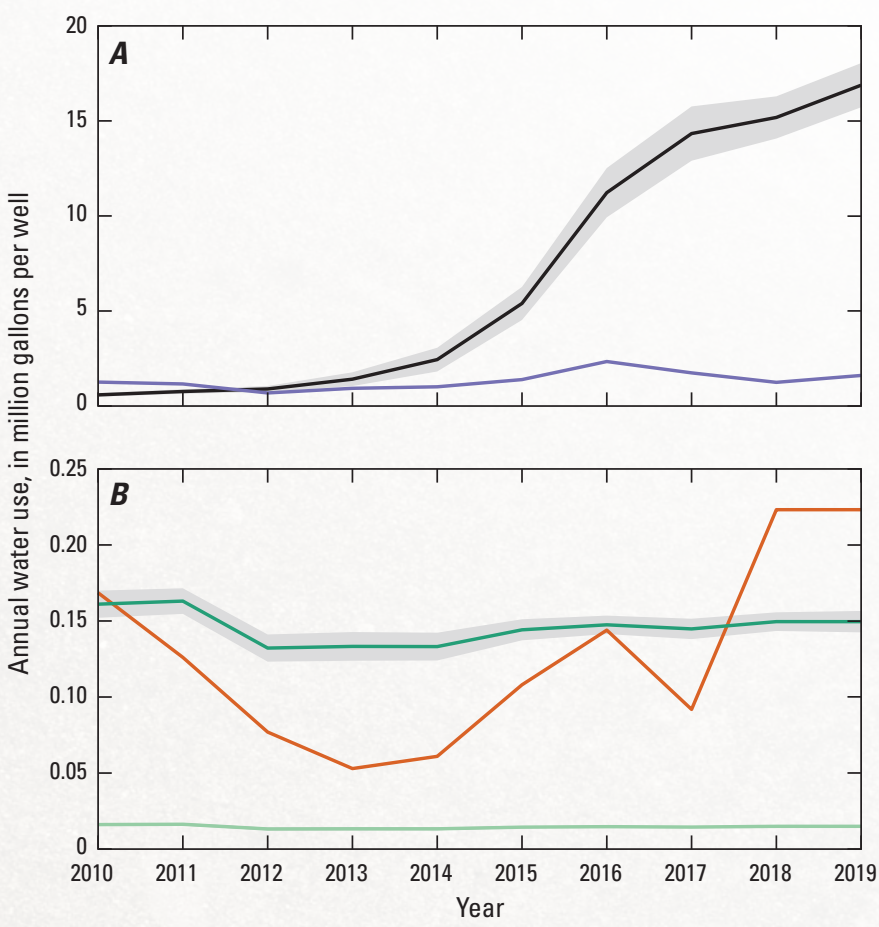

EXPLANATION

95-percent confidence interval-Range of values that 95 percent of the time contain the actual value of the parameter (Helsel and others, 2020)

Estimated from linear regression models

$\begin{array}{lll}\text { Direct-Hydraulic fracturing } \quad-\quad \text { Direct-Drilling } \\ \quad \text { Ancillary } & \text { Direct-Cementing } \\ & \text { Indirect } & \end{array}$

Figure 4. Annual estimates of direct, indirect, and ancillary water use in the Permian Basin from 2010 to 2019. A, Hydraulic fracturing (direct) and ancillary uses. $B$, Indirect, drilling (direct), and cementing (direct) uses (modified from fig. 8 in Valder and others, 2021).

\section{Comparing the COG Reservoirs between the Williston and Permian Basins}

Appreciable accumulations of COG hydrocarbons in the Williston Basin are present in the Upper Devonian to Lower Mississippian Three Forks and Bakken Formations (fig. 5; Sandberg and Hammond, 1958; U.S. Energy Information Administration, 2020a). Appreciable accumulations of COG hydrocarbons in the Midland and Delaware Basins of the greater Permian Basin (fig 1; U.S. Energy Information Administration, 2020b) are present in the lower Permian (Leonardian) Spraberry Formation (fig. 6) (Midland Basin) and time-equivalent Bone Spring Formation (Delaware Basin), and in the underlying lower Permian to Upper Pennsylvanian (Leonardian to Missourian) Wolfcamp shale (fig. 6) (informal name; Gaswirth and others, 2016, 2018, and references therein) in the Midland and Delaware Basins.

The COG reservoirs in the Williston and Permian Basins consist of stacked shale units, but the Permian Basin units are thicker and contain as many as 10 stacked shale intervals (Scanlon and others, 2017). The features in the Permian Basin that contain the stacked shale intervals are the Delaware and Midland Basins, which are separated by the shallow Central Basin Platform (Valder and others, 2021). These differences in geology mean that the Permian Basin has more intervals within its stratigraphic sequence for potential hydraulic fracturing compared to the Williston Basin. 


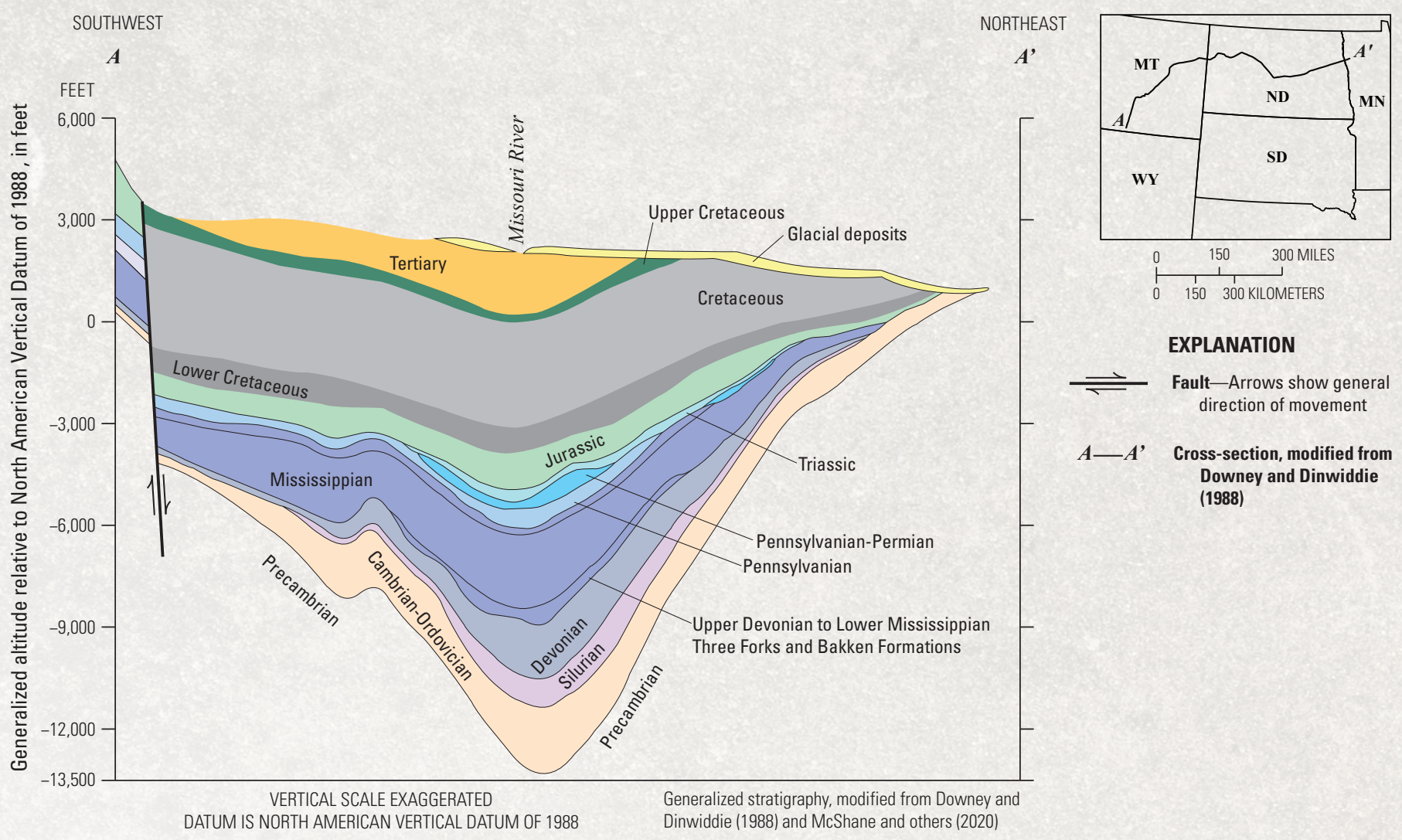

Figure 5. Generalized cross section showing the stratigraphy of the Williston Basin (modified from Downey and Dinwiddie, 1988; fig. 2 in McShane and others, 2020).

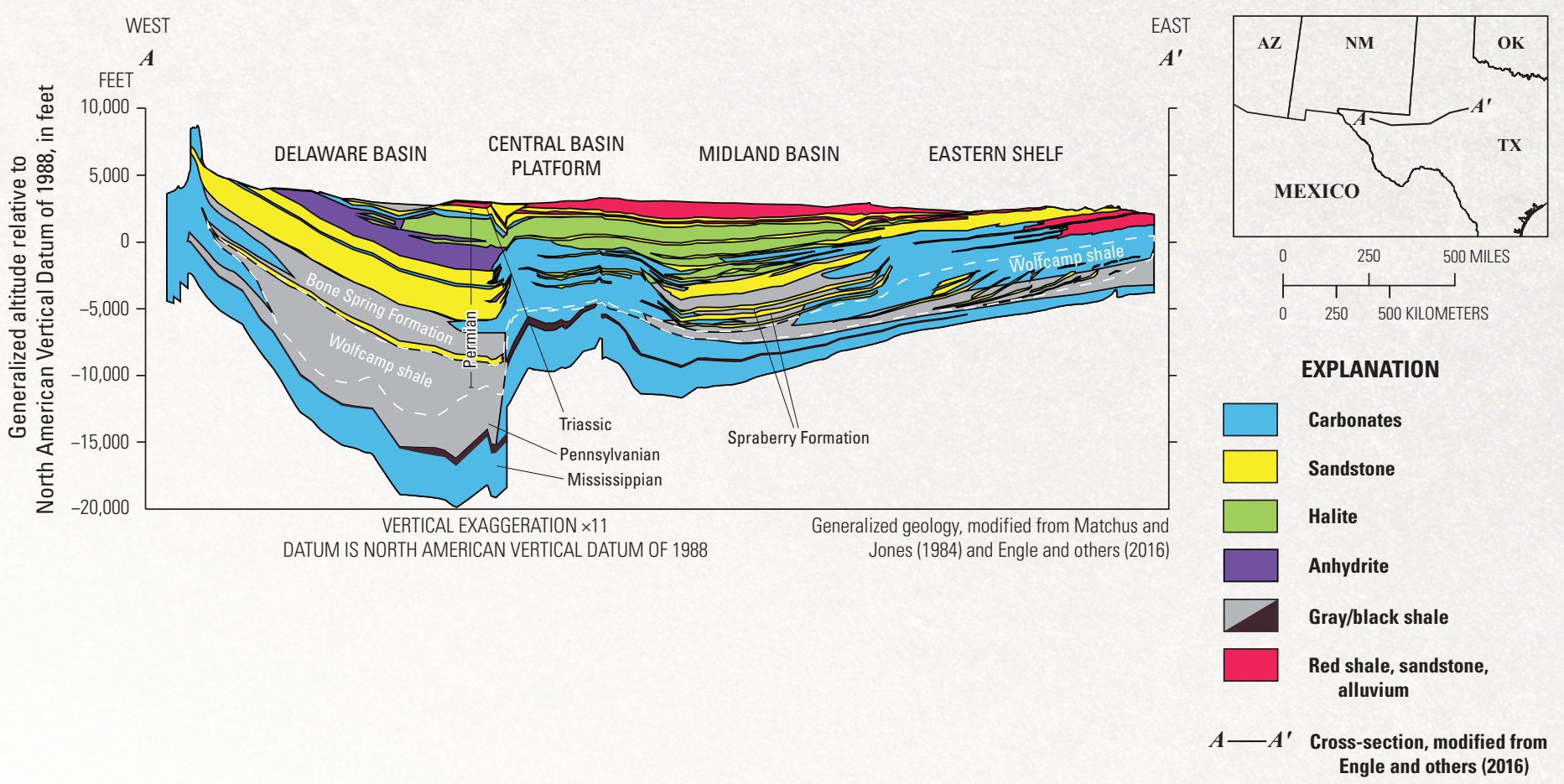

Figure 6. Generalized cross section showing the stratigraphy of the Permian Basin (modified from Matchus and Jones, 1984; Engle and others, 2016; fig. 2 in Valder and others, 2021). 


\section{Comparing Water Use Between the Williston Basin and Permian Basin}

Estimates of water use for COG development in the Williston Basin (McShane and others, 2020) and the Permian Basin (Valder and others, 2021) indicate a similar trend of increased direct water use per well because of changes in hydraulic fracturing water needs from 2010 to 2015. Water use increased in the Williston Basin, from 1.4 Mgal per well in 2010 to $4.7 \mathrm{Mgal}$ per well in 2015 (fig. $5 \mathrm{~A}$ ) and increased similarly in the Permian Basin from 0.6 Mgal per well in 2010 to $5.4 \mathrm{Mgal}$ per well in 2015 (fig. 7B). However, by 2017, hydraulic fracturing water use per well was much greater in the Permian Basin (14.3 Mgal per well; fig. $5 B$ ) than in the Williston Basin (8.4 Mgal per well; fig. 7A). The differences in water use per well over time and between the basins are likely caused by the potential differences in the length of well laterals (the horizontal part of the wellbore), the hydraulic fracturing practices of operators, the geologic properties of the COG reservoirs, and the supply and cost of local surface water or groundwater.

Conversely, the average indirect water use per well was less in the Permian Basin than in the Williston Basin. This difference may be the result of differences in data sources between the two basins or a difference in water uses in the basin for items such as well pad upkeep, dust abatement, and crew camps. The Permian Basin also has water supply challenges for oil and gas extraction because of the semiarid climate, growing population, and limited availability of groundwater and surface-water resources (Kondash and Vengosh, 2015). The COG conceptual model and analytical framework includes procedures that can be adapted to other areas of COG production throughout the United States to estimate water use (McShane and McDowell, 2021). Currently (2021), the USGS is working to operationalize the model and framework developed in this phase of the study.

\section{References Cited}

Ball, G.P., Galanter, A.E., McDowell J.S., Houston, N.A., McShane, R.R., Haines, S., Verela, B., Valder, J.F., and Thamke, J.N., 2020, Data to estimate water use associated with continuous oil and gas development, Permian Basin, United States, 1980-2019: U.S. Geological Survey data release, accessed September 13, 2021, at https://doi.org/10.5066/P9LAWIPH.

Bureau of Economic Geology, 2008, Integrated synthesis of the Permian Basin project GIS data: Bureau of Economic Geology digital data, accessed May 28, 2020, at https://www.beg.utexas.edu/resprog/permianbasin/gis_data/ PBGSP_GIS.zip.

Carter, J.M., Macek-Rowland, K.M., Thamke, J.N., and Delzer, G.C., 2016, Estimating national water use associated with unconventional oil and gas development: U.S. Geological Survey Fact Sheet 2016-3032, 6 p. [Also available at https://doi.org/10.3133/fs20163032.]

Downey, J.S., and Dinwiddie, G.A., 1988, The regional aquifer system underlying the Northern Great Plains in parts of Montana, North Dakota, South Dakota, and Wyoming - Summary: U.S. Geological Survey Professional Paper 1402-A, 64 p. [Also available at https://doi.org/10.3133/pp1402A.]

Engle, M.A., Reyes, R.R., Varonka, M.S., Orem, W.H., Ma, L., Ianno, A.J., Schell, T.M., Xu, P., and Carroll, K.C., 2016, Geochemistry of formation waters from the Wolfcamp and "Cline" shales - Insights into brine origin, reservoir connectivity, and fluid flow in the Permian Basin, USA: Chemical Geology, v. 425, p. 76-92. [Also available at https://doi.org/10.1016/j .chemgeo.2016.01.025.]

FracFocus, 2020, FracFocus Chemical Disclosure Registry: FracFocus database, accessed May 28, 2020, at https://fracfocus.org/data-download.
A. Williston Basin

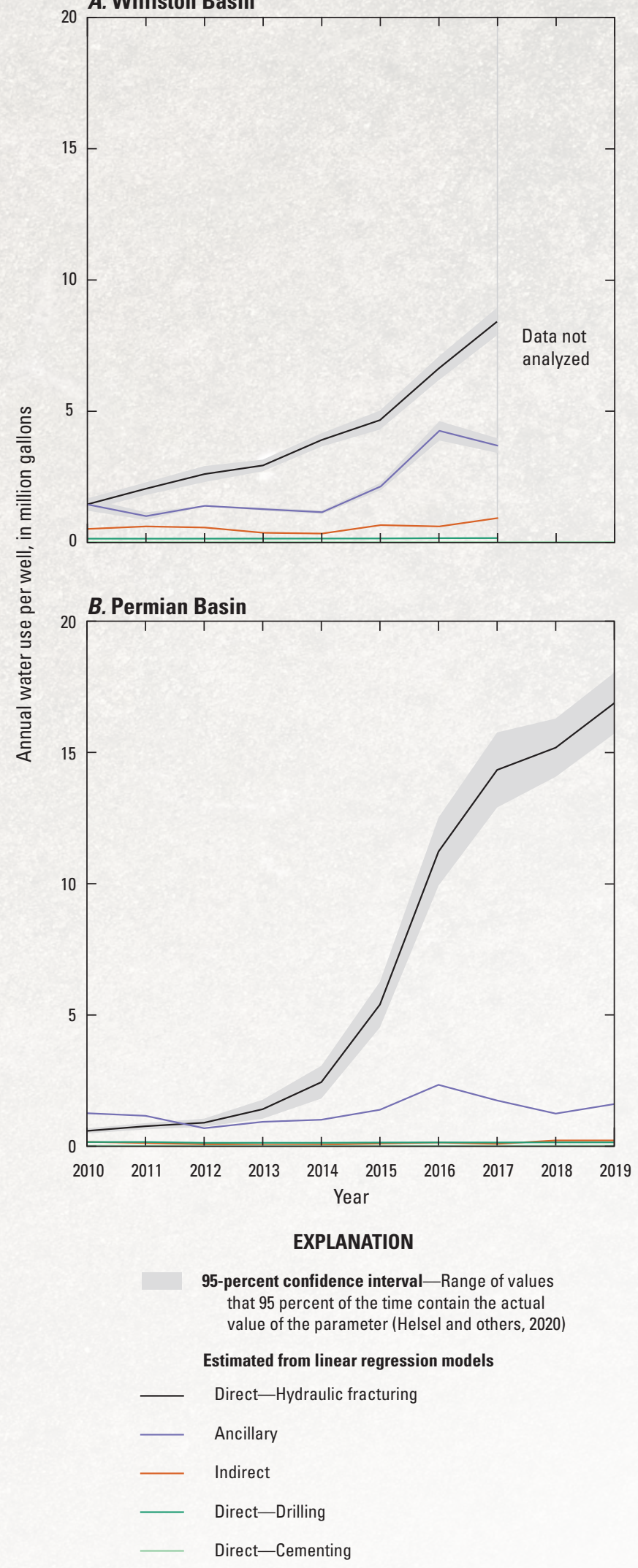

Figure 7. Annual estimates of direct, indirect, and ancillary water use. A, Williston Basin from 2010 to 2017. B, Permian Basin from 2010 to 2019 (modified from fig. 11 in Valder and others, 2021). 
Gaswirth, S.B., 2018, USGS National and Global Oil and Gas Assessment Project-Permian Basin Province, Delaware Basin, Wolfcamp Shale and Bone Spring assessment units and input data: U.S. Geological Survey data release, accessed September 13, 2021, at https://doi.org/10.5066/P9WOUJD3.

Gaswirth, S.B., French, K.L., Pitman, J.K., Marra, K.R., Mercier, T.J., LeathersMiller, H.M., Schenk, C.J., Tennyson, M.E., Woodall, C.A., Brownfield, M.E., Finn, T.M., and Le, P.A., 2018, Assessment of undiscovered continuous oil and gas resources in the Wolfcamp shale and Bone Spring Formation of the Delaware Basin, Permian Basin Province, New Mexico and Texas, 2018: U.S. Geological Survey Fact Sheet 2018-3073, 4 p. [Also available at https://doi.org/10.3133/fs20183073.]

Gaswirth, S.B., Marra, K.R., Lillis, P.G., Mercier, T.J., Leathers-Miller, H.M., Schenk, C.J., Klett, T.R., Le, P.A., Tennyson, M.E., Hawkins, S.J., Brownfield, M.E., Pitman, J.K., and Finn, T.M., 2016, Assessment of undiscovered continuous oil resources in the Wolfcamp shale of the Midland Basin, Permian Basin Province, Texas, 2016: U.S. Geological Survey Fact Sheet 2016-3092, 4 p. [Also available at https://doi.org/10.3133/fs20163092.]

Helsel, D.R., Hirsch, R.M., Ryberg, K.R., Archfield, S.A., and Gilroy, E.J., 2020, Statistical methods in water resources: U.S. Geological Survey Techniques and Methods, book 4, chapter A3, 458 p., accessed September 13, 2021, at https://doi.org/10.3133/tm4A3. [Supersedes USGS Techniques of WaterResources Investigations, book 4, chapter A3, version 1.1.]

IHS Markit, 2020, U.S. well database: IHS Markit web page, accessed August 27, 2020, at https://ihsMarkit.com/industry/oil-gas.html.

Jiang, M., Hendrickson, C.T., and VanBriesen, J.M., 2014, Life cycle water consumption and wastewater generation impacts of a Marcellus shale gas well: Environmental Science \& Technology, v. 48, no. 3, p. 1911-1920. [Also available at https://doi.org/10.1021/es4047654.]

Kondash, A., and Vengosh, A., 2015, Water footprint of hydraulic fracturing: Environmental Science \& Technology Letters, v. 2, no. 10, p. 276-280. [Also available at https://doi.org/10.1021/acs.estlett.5b00211.]

Matchus, E.J., and Jones, T.S., 1984, East-west cross section through Permian Basin of west Texas: West Texas Geological Society, publication no. 84-79.

McShane, R.R., Barnhart, T.B., Valder, J.F., Haines, S.S., Macek-Rowland, K.M., Carter, J.M., Delzer, G.C., and Thamke, J.N., 2020, Estimates of water use associated with continuous oil and gas development in the Williston Basin, North Dakota and Montana, 2007-17: U.S. Geological Survey Scientific Investigations Report 2020-5012, 26 p., accessed September 13, 2021, at https://doi.org/10.3133/sir20205012.

McShane, R.R., and McDowell J.S., 2021, R Scripts and results of estimated water use associated with continuous oil and gas development, Permian Basin, United States, 2010-2019: U.S. Geological Survey data release, accessed September 13, 2021, at https://doi.org/10.5066/P9JIOU3V.

Parameter-Elevation Regressions on Independent Slopes Model (PRISM) Climate Group, 2020, PRISM climate data: Oregon State University, accessed September 6, 2020, at https://prism.oregonstate.edu/.

Sandberg, C.A., and Hammond, C.R., 1958, Devonian System in Williston basin and central Montana: The American Association of Petroleum Geologists Bulletin, v. 42, no. 10, p. 2293-2334.

Scanlon, B.R., Reedy, R.C., Male, F., and Walsh, M., 2017, Water issues related to transitioning from conventional to unconventional oil production in the Permian Basin: Environmental Science \& Technology, v. 51, no. 18, p. 10903-10912. [Also available at https://doi.org/10.1021/acs.est.7b02185.]

Tangen, B.A., Haines, S.S., Preston, T.M., and Thamke, J.N., 2014, Oil and gas production, aquatic resources, and brine contamination in the Williston Basin, United States, chap. A of Gleason, R.A., and Tangen, B.A., eds., Brine contamination to aquatic resources from oil and gas development in the Williston Basin, United States: U.S. Geological Survey Scientific Investigations Report 2014-5017, p. 5-20, accessed September 2, 2021, at https://doi.org/10.3133/ $\operatorname{sir} 20145017$.

Texas Water Development Board, 2020, Historical water use estimates: Texas Water Development Board web page, accessed June 19, 2020, at http://www.twdb.texas.gov/waterplanning/waterusesurvey/estimates/ index.asp.

U.S. Census Bureau, 2020, Intercensal state and county population estimates: U.S. Census Bureau digital data, accessed September 6, 2020, at https://www.census.gov/programs-surveys/popest/data/tables.html.
U.S. Energy Information Administration, 2017, Permian Basin-Boundary, structure, and tectonic features: U.S. Energy Information Administration digital data, accessed May 28, 2020, at https://www.eia.gov/maps/map_data/ PermianBasin_Boundary_Structural_Tectonic.zip.

U.S. Energy Information Administration, 2020a, North Dakota State energy profile: U.S. Energy Information Administration web page, accessed September 6, 2021, at https://www.eia.gov/state/print.php?sid=ND.

U.S. Energy Information Administration, 2020b, Permian Basin-Part 2-Wolfcamp shale play of the Midland Basin-Geology review: Washington, D.C., U.S. Department of Energy, 38 p. [Also available at https://www.eia.gov/maps/pdf/Permian_Wolfcamp_Midland_EIA reportII.pdf.]

U.S. Geological Survey, 2020, USGS water data for the Nation: U.S. Geological Survey National Water Information System database, accessed March 2020, at https://doi.org/10.5066/F7P55KJN.

Valder, J.F., McShane, R.R., Barnhart, T.B., Sando, R., Carter, J.M., and Lundgren, R.F., 2018, Conceptual model to assess water use associated with the life cycle of unconventional oil and gas development: U.S. Geological Survey Scientific Investigations Report 2018-5027, 22 p., accessed September 13, 2021, at https://doi.org/10.3133/sir20185027.

Valder, J.F., McShane, R.R., Barnhart, T.B., Wheeling, S.L., Carter, J.M., MacekRowland, K.M., Delzer, G.C., and Thamke, J.N., 2019, Analytical framework to estimate water use associated with continuous oil and gas development: U.S. Geological Survey Scientific Investigations Report 2019-5100, 19 p., accessed September 13, 2021, at https://doi.org/10.3133/sir20195100.

Valder, J.F., McShane, R.R., Thamke, J.N., McDowell, J.S., Ball, G.P., Houston, N.A., and Galanter, A.E., 2021, Estimates of water use associated with continuous oil and gas development in the Permian Basin, Texas and New Mexico, 2010-19: U.S. Geological Survey Scientific Investigations Report 2021-5090, 27 p., accessed September 13, 2021, at https://doi.org/10.3133/sir20215090.

\section{Acknowledgments}

The authors thank the Texas Water Development Board, the New Mexico Office of the State Engineer, the New Mexico Oil Conservation Division, and the Railroad Commission of Texas for providing data for this study. This study was supported by the U.S. Geological Survey Water Availability and Use Science Program.

This fact sheet is based on the following report:

Valder, J.F., McShane, R.R., Thamke, J.N., McDowell, J.S., Ball, G.P., Houston, N.A., and Galanter, A.E., 2021, Estimates of water use associated with continuous oil and gas development in the Permian Basin, Texas and New Mexico, 2010-19: U.S. Geological Survey Scientific Investigations Report 2021-5090, 27 p., https://doi.org/10.3133/ sir20215090.

By Natalie A. Houston, Grady P. Ball, Amy E. Galanter, Joshua F. Valder, Ryan R. McShane, Joanna N. Thamke, and Jeremy S. McDowell

For more information, contact:

Director, Oklahoma-Texas Water Science Center

U.S. Geological Survey

1505 Ferguson Lane

Austin, TX 78754-4501

For more information, visit: https://www.usgs.gov/centers/ot-water

Publishing support provided by the

Rolla Publishing Service Center

ISSN 2327-6932 (online) https://doi.org/10.3133/fs20213053 